\title{
Contamination of Environment with Polycyclic Aromatic Hydrocarbons in India
}

\author{
Khageshwar Singh Patel ${ }^{*}$, Shobhana Ramteke1, Yogita Naik1, Bharat Lal Sahu', \\ Saroj Sharma², Jutta Lintelmann ${ }^{3}$, Matuschek Georg ${ }^{3}$ \\ ${ }^{1}$ School of Studies in Chemistry/Environmental Science, Pt. Ravishankar Shukla University, Raipur, India \\ ${ }^{2}$ Department of Chemistry, Devi Rathi Mahila Mahavidhaya, Rajnandagaon, India \\ ${ }^{3}$ GSF-Forschungszentrum für Umwelt und Gesundheit, Institut für Ökologische Chemie, Neuherberg, Germany \\ Email: patelks_55@hotmail.com
}

Received 23 September 2015; accepted 13 November 2015; published 16 November 2015

Copyright $@ 2015$ by authors and Scientific Research Publishing Inc.

This work is licensed under the Creative Commons Attribution International License (CC BY).

http://creativecommons.org/licenses/by/4.0/

(c) (i) Open Access

\begin{abstract}
Environment in India is contaminated with polycyclic aromatic hydrocarbons (PAHs) due to occurring of large anthropogenic activities i.e. fuel combustion, mineral roasting and biomass burning. Hence, contamination of 13 toxic PAHs: phenanthrene, anthracene, fluoranthene, pyrene, benz (a) anthracene, ben-zo (b) fluoranthene, benzo (k) fluoranthene, benzo (a) pyrene, benzo (ghi) perylene, dibenz (ah) anthracene, indeno1,2,3-(cd) pyrene, coronene and coronene in the environment (i.e. ambient particulate matter, road dust, sludge and sewage) of the most industrialized area: Raipur city, India is described. The $\sum \mathrm{PAH}_{13}$ concentration in the 16 environment materials was ranged from $7980-1,051,300 \mu \mathrm{g} / \mathrm{kg}$ with mean value of $172,613 \pm 154,726 \mu \mathrm{g} / \mathrm{kg}$. The concentration variations, toxicities and sources of the PAHs in various environmental compartments are discussed.
\end{abstract}

\section{Keywords}

Polycyclic Aromatic Hydrocarbons, Dust, Sewage Sludge

\section{Introduction}

Polycyclic aromatic hydrocarbons (PAHs) are a large group of chemical compounds, I, with a similar structure comprising two or more joined aromatic carbon rings [1]. The compounds are formed by combustion of fuels, biomass and waste materials [2]. Polycyclic aromatic compounds are carcinogenic and mutagenic compounds, causing irreversible changes in the structure and functioning of living organisms [3]. There are thousands of PAH compounds in the environment but 13 compounds i.e. naphthalene, phenanthrene, anthracene, fluoranthene,

*Corresponding author.

How to cite this paper: Patel, K.S., Ramteke, S., Naik, Y., Sahu, B.L., Sharma, S., Lintelmann, J. and Georg, M. (2015) Contamination of Environment with Polycyclic Aromatic Hydrocarbons in India. Journal of Environmental Protection, 6, $1268-1278$. http://dx.doi.org/10.4236/jep.2015.611111 
pyrene, chrysene, benz (a) anthracene, benzo (b) fluoranthene, benzo (k) fluoranthene, benzo (a) pyrene, benzo (ghi) perylene, dibenz (ah) anthracene, indeno1,2,3-(cd) pyrene and coronene of the increased environmental and health interests. These compounds differ substantially in their physical, chemical and toxicological properties and therefore, their quantification in the environment is needed. The most potent carcinogens have been shown to be benzo [a] anthracene, benzo [a] pyrene and dibenz [ah] anthracene. They are multimedia contaminants, reported at elevated levels in several environmental samples i.e. dust, particulate matter, sludge and sewage of various region of the World [4]-[26].<smiles>c1ccc(Cc2ccccc2-c2ccccc2)cc1</smiles>

\section{Methods and Materials}

\subsection{Selection of Sampling Sites}

Raipur $\left(21^{\circ} 23^{\prime} \mathrm{N}, 81^{\circ} 63^{\prime} \mathrm{E}\right)$ is the capital city of the Chhattisgarh state with population of $\approx 2$ million. The Raipur city is now becoming an important regional commercial and industrial destination for the coal, power, steel and aluminum industries. Several steel rolling mills, sponge iron plants, steel plants, agro-industries, thermal power plants and vehicles $\left(>1.0 \times 10^{5}\right)$ are emitting effluents in and around the city.

\subsection{Collection of Samples}

The road dust, sludge and sewage samples were collected using a stainless-steel scoop from 13 locations of Raipur city in February 2010, Figure 1. They were kept in 250-mL glass bottle and dried at $30^{\circ} \mathrm{C}$ in an oven for overnight. The samples were crushed into fine particles by mortar and sieved out the particles of mesh size $<0.1$ $\mathrm{mm}$. The samples were stored in aluminum foil.

The coarse particulate matter $\left(\mathrm{PM}_{10}\right)$ and fine particulate matter $\left(\mathrm{PM}_{2.5}\right)$ were collected by using Partisol Model 2300 Sequential speciation air sampler. The sampler was installed at the roof of the building, $\approx 10 \mathrm{~m}$ above from the ground level at residential site: Dagania, Raipur. Both $\mathrm{PM}_{2.5}$ and $\mathrm{PM}_{10}$ were collected simultaneously over $47 \mathrm{~mm}$ quartz fiber filters housed in molded filter cassette. The sampler was run for 24 hrs (6.00 $\mathrm{am}-6.00 \mathrm{am}$ ) at flow rate of $10 \mathrm{~L} / \mathrm{min}$. One sample blank was used for collection of both $\mathrm{PM}_{10}$ and $\mathrm{PM}_{2.5}$. The loaded filters were dismounted, brought to laboratory, and heated up to $30^{\circ} \mathrm{C}$ for 6 hrs to remove the moisture contents. The filters were transferred into the desiccator, and finally weighted to record the particulate contents.

\subsection{Analysis of Carbons}

The CHNSO-IRMS Analyzer by SV Instruments Analytica Pvt Ltd. was used for analysis of the total carbon (TC). Three carbons i.e. elemental carbon (EC), organic carbon (OC) and carbonate carbon (CC) were analyzed in the samples. The total carbn (TC) sample was oxidized with $\mathrm{O}_{2}$ at $1020^{\circ} \mathrm{C}$ with constant helium flow by measuring the resulting $\mathrm{CO}_{2}$ with thermal conductivity detector. The $\mathrm{CC}$ content was analyzed by treating the sample with $\mathrm{HCl}$ acid in the $\mathrm{CO}_{2}$ free atmosphere. The resulting $\mathrm{CO}_{2}$ was measured by coulometric titration method. The OC content was analyzed by titration method using $\mathrm{K}_{2} \mathrm{Cr}_{2} \mathrm{O}_{7}$ as oxidant, and the excess of $\mathrm{K}_{2} \mathrm{Cr}_{2} \mathrm{O}_{7}$ was determined by titration with the $\mathrm{FeSO}_{4} \cdot 7 \mathrm{H}_{2} \mathrm{O}$ solution. The $\mathrm{EC}$ content was evaluated by using following equation.

$$
\mathrm{EC}=\mathrm{TC}-(\mathrm{OC}+\mathrm{CC})
$$

\subsection{Analysis of PAHs}

The PAH samples were analyzed by capillary gas chromatography (Varian STAR 3400 CX) using temperature programmable splitless injection, a fused silica RTX5-MS column and ion trap mass spectrometric detection [27].

\section{Results and Discussion}

\subsection{Carbon Concentration}

All samples are colored, ranging from brown to black, depending on the EC content. The content of EC, OC and 


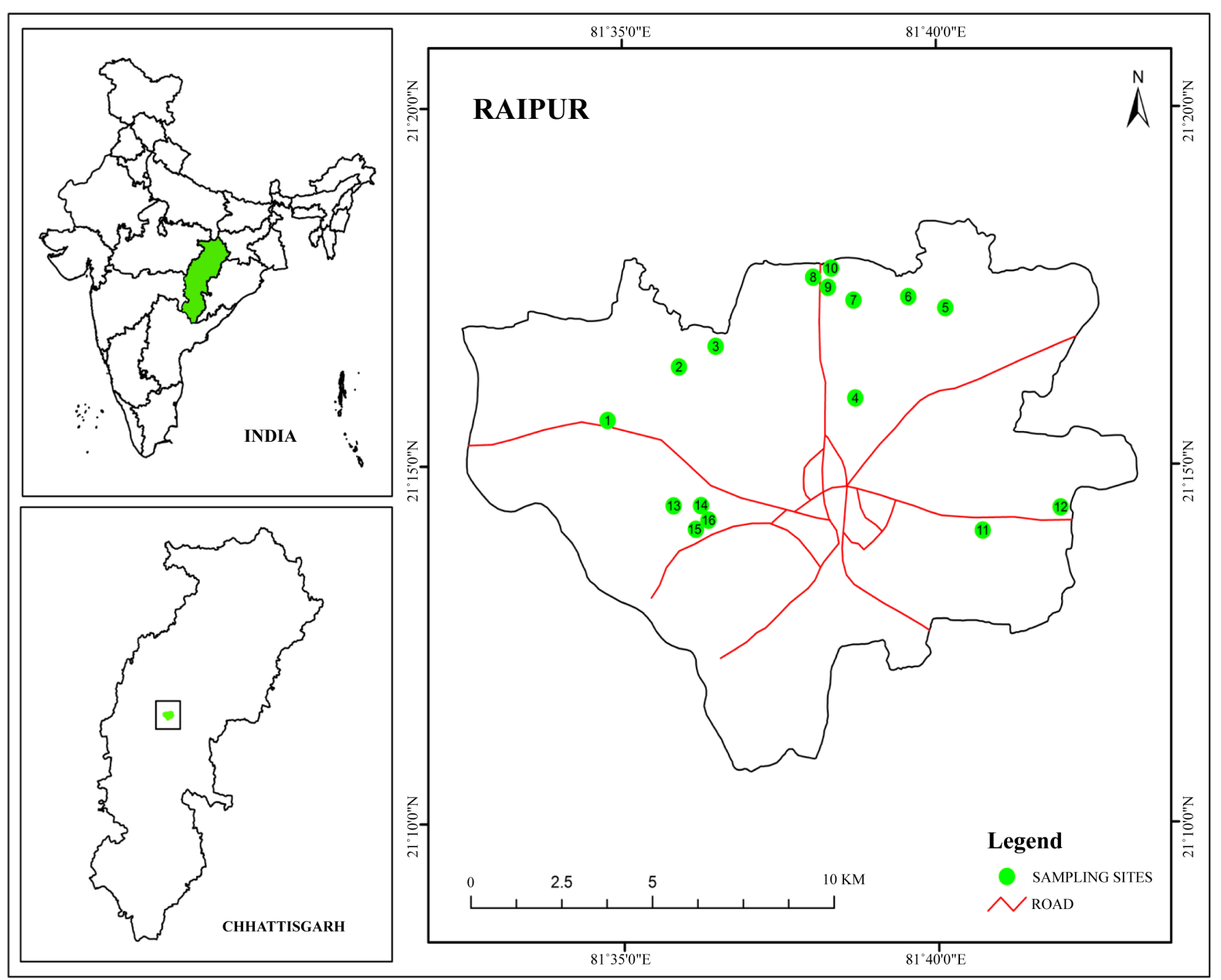

Figure 1. Representation of sampling locations.

CC in the 16 environmental shown in Table 1. Relatively high content of EC in all samples was achieved, ranging from $6.5 \%-13.5 \%$ with mean value of $8.4 \% \pm 1.1 \%$. Very low content of OC and CC was observed in the dust, sludge and sewage samples unlikely to PM samples may be due to their degradation and water solubility, Figure 1. The EC content with the OC and CC had good relation $(r=0.94-0.96)$, indicating origin from the similar sources.

\subsection{PAHs Concentration}

The chemical characteristics of 13 PAHs i.e. phenanthrene (Phe), anthracene (Ant), fluoranthene (Fla), pyrene (Pyr), benz [a] anthracene (Baa), chrysene (Cry), benzo [b] fluoranthene (Bbf), benzo [k] fluoranthene (Bkf), benzo [a] pyrene (Bap), benzo [ghi] perylene (Bgh), dibenz [a,h] anthracene (Dba), indeno [1,2,3-cd] pyrene (Ind) and coronene is summarized in Table 2. The content of 13 PAHs in 16 environmental samples is presented in Table 3. The sum of total concentration of PAHs $\left(\Sigma \mathrm{PAH}_{13}\right)$ in the road dust of Raipur city $(\mathrm{n}=8)$ was ranged from 10,427 - 26,031 $\mu \mathrm{g} / \mathrm{kg}$ with mean value of $15,282 \pm 3377 \mu \mathrm{g} / \mathrm{kg}$. The highest concentration of the $\mathrm{\Sigma PAH}_{13}$ was observed at site no 5 (i.e. Birgaon) due to higher industrial and traffic emissions, Figure 2. Similarly, the concentration of $\Sigma \mathrm{PAH}_{13}$ in the SL, MW, AW and TPPW was found to be 7980, 9669, 10,570 and $8326 \mu \mathrm{g} / \mathrm{kg}$, respectively. No signal for Cor was detected in the environmental samples i.e. RD, SL, MW, AW and TPPW samples. The major fraction of PAHs in the RD, AW and TPPW samples was contributed by three compounds i.e. Phe, Fla and Pyr, Figure 3. A different distribution pattern of PAHs in the SL and MW samples was observed, dominated by Pyr and Bgh contents, Figure 3. The concentration of $\Sigma \mathrm{PAHs}$ in the $\mathrm{PM}_{10}$ and $\mathrm{PM}_{2.5}$ was strongly enriched, >25-folds higher than the road dust with appearing of strong Cor signal. The $\mathrm{PM}_{2.5}$ sample 
Table 1. Chemical characteristics of PAHs.

\begin{tabular}{ccccc}
\hline S. No. & PAHs & No. of rings & Abbreviation & Formula \\
\hline 1 & Phenanthrene & 3 & Phe & $\mathrm{C}_{14} \mathrm{H}_{10}$ \\
2 & Anthracene & 3 & Ant & $\mathrm{C}_{14} \mathrm{H}_{10}$ \\
3 & Fluoranthene & 4 & Fla & $\mathrm{C}_{16} \mathrm{H}_{10}$ \\
4 & Pyrene & 4 & Pyr & $\mathrm{C}_{16} \mathrm{H}_{10}$ \\
5 & Benz [a] anthracene & 4 & Baa & $\mathrm{C}_{18} \mathrm{H}_{12}$ \\
6 & Chrysene & 4 & Cry & $\mathrm{C}_{18} \mathrm{H}_{12}$ \\
7 & Benzo [b] fluoranthene & 5 & Bbf & $\mathrm{C}_{20} \mathrm{H}_{12}$ \\
8 & Benzo [k] fluoranthene & 5 & Bkf & $\mathrm{C}_{20} \mathrm{H}_{12}$ \\
9 & Benzo [a] pyrene & 5 & Bap & $\mathrm{C}_{20} \mathrm{H}_{12}$ \\
10 & Dibenz [ah] anthracene & 5 & Dba & $\mathrm{C}_{22} \mathrm{H}_{14}$ \\
11 & Benzo [ghi] perylene & 6 & Bgh & $\mathrm{C}_{22} \mathrm{H}_{12}$ \\
12 & Indeno [1,2,3-cd] pyrene & 6 & Ind & $\mathrm{C}_{22} \mathrm{H}_{12}$ \\
13 & Coronene & 6 & Cor & $\mathrm{C}_{24} \mathrm{H}_{12}$ \\
\hline
\end{tabular}

Table 2. Concentration of carbons and polycyclic aromatic hydrocarbons in environmental samples.

\begin{tabular}{ccccccc}
\hline S. No. & Sample type & Location & BC, $\%$ & OC, $\%$ & CC, $\%$ & IPAHs, $\mathrm{mg} / \mathrm{kg}$ \\
\hline 1 & $\mathrm{RD} 1$ & Tatibandh & 6.5 & 0.32 & 0.45 & 10.4 \\
2 & $\mathrm{RD} 2$ & Hirapur & 6.7 & 0.38 & 0.47 & 11.2 \\
3 & $\mathrm{RD} 3$ & Sarora & 6.9 & 0.34 & 0.41 & 13.1 \\
4 & $\mathrm{RD} 4$ & Khamtarai & 6.8 & 0.36 & 0.47 & 14.1 \\
5 & $\mathrm{RD} 5$ & Birgaon & 10.4 & 0.53 & 0.68 & 26.0 \\
6 & $\mathrm{RD6}$ & Urla & 7.2 & 0.39 & 0.52 & 14.2 \\
7 & $\mathrm{RD} 7$ & Sankra & 8.2 & 0.42 & 0.56 & 16.7 \\
8 & $\mathrm{RD} 8$ & Siltara & 8.2 & 0.44 & 0.52 & 16.5 \\
9 & $\mathrm{SL}$ & Siltara & 7.5 & 0.03 & 0.12 & 8.0 \\
10 & $\mathrm{MW}$ & Siltara & 7.6 & 0.03 & 0.11 & 9.7 \\
11 & $\mathrm{TPPW}$ & Monate, Urla & 8.9 & 0.04 & 0.17 & 8.3 \\
12 & $\mathrm{AW}$ & IGAU & 9.0 & 0.05 & 0.19 & 10.6 \\
13 & $\left(\mathrm{PM}_{10}\right) 1$ & Dagania & 6.8 & 5.8 & 4.6 & 505 \\
14 & $\left(\mathrm{PM}_{10}\right) 2$ & Dagania & 6.7 & 5.6 & 4.2 & 347 \\
15 & $\left(\mathrm{PM}_{2.5}\right) 1$ & Dagania & 13.5 & 8.3 & 5.1 & 1051 \\
16 & $\left(\mathrm{PM}_{2.5}\right) 2$ & Dagania & 13.2 & 8.1 & 5.0 & 700 \\
\hline
\end{tabular}

RD, SL, MW, TPPW, AW, $\mathrm{PM}_{10}$ and $\mathrm{PM}_{2.5}$ represent road dust, sludge, municipal/sewage waste, thermal power plant waste, agricultural waste, coarse particulate matter and fine particulate matter, respectively.

was dominated by higher PAHs i.e. Bbf, Bgh and Ind, Figure 4. Whereas, the $\mathrm{PM}_{10}$ sample was dominated by PAHs i.e. Fla, Pyr, Bgh and Ind, Figure 4. The PAHs content in the dust was negatively and fairly correlated with particle size $(r=-0.89)$, Figure 5 . The concentration of the PAHs in the environmental samples of studied area was found to be comparable to the other parts of the country and World [4]-[25]. 


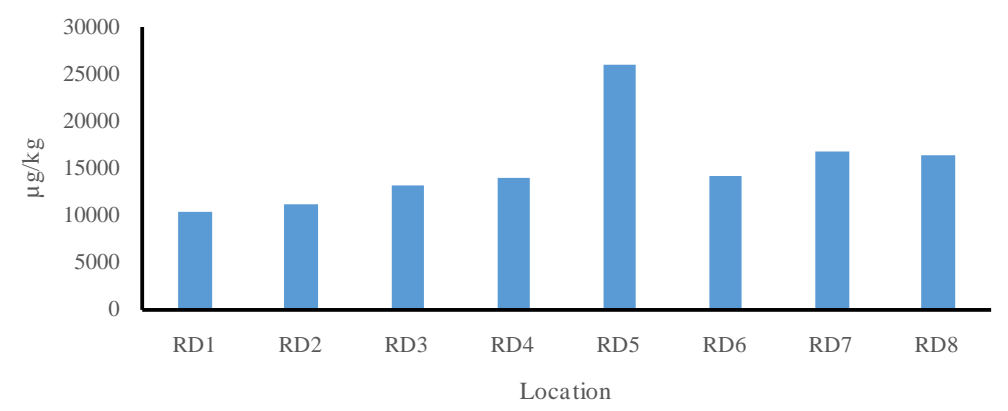

Figure 2. Spatial distribution of PAHs in the road dust.

(a)

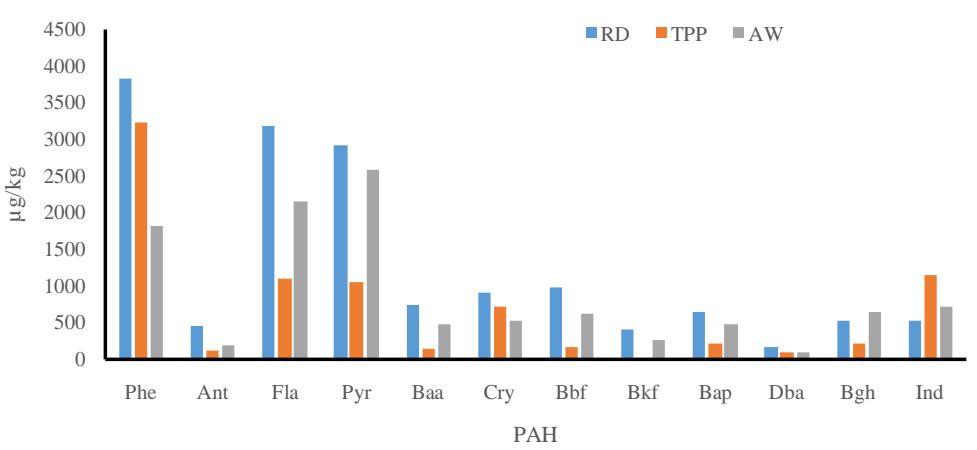

(b)

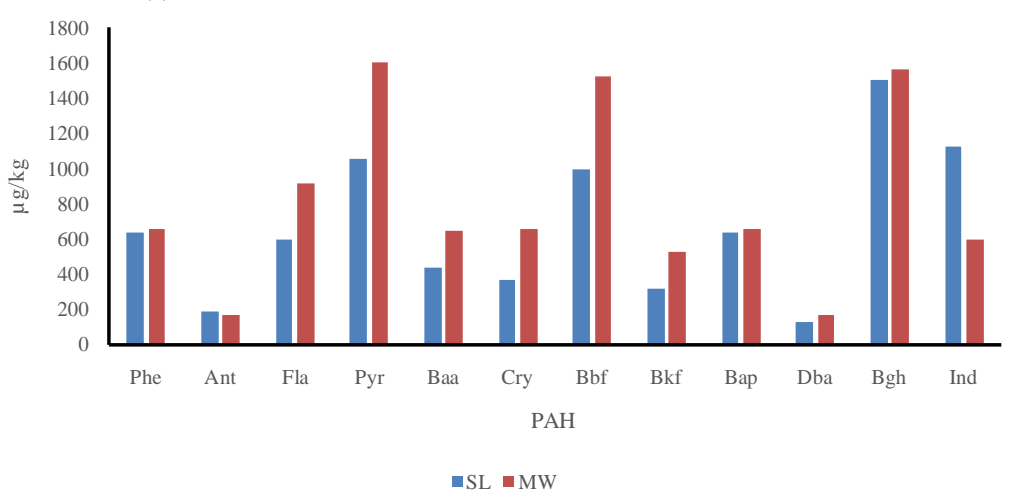

Figure 3. Distribution of PAHs in dust (RD), thermal power plant ash (TPPA), agricultural waste (AW), sludge (SL) and municipal waste (MW).

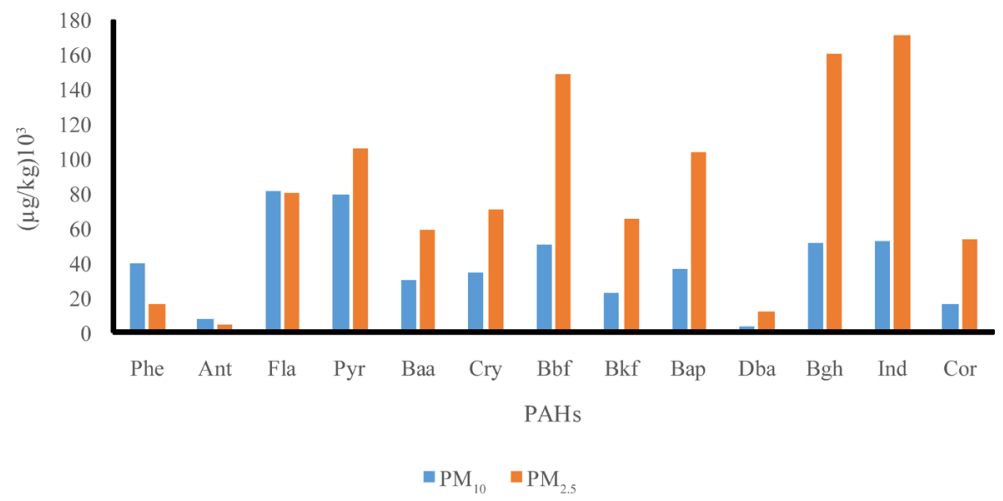

Figure 4. Distribution of PAHs in the $\mathrm{PM}_{10}$ and $\mathrm{PM}_{2.5}$. 


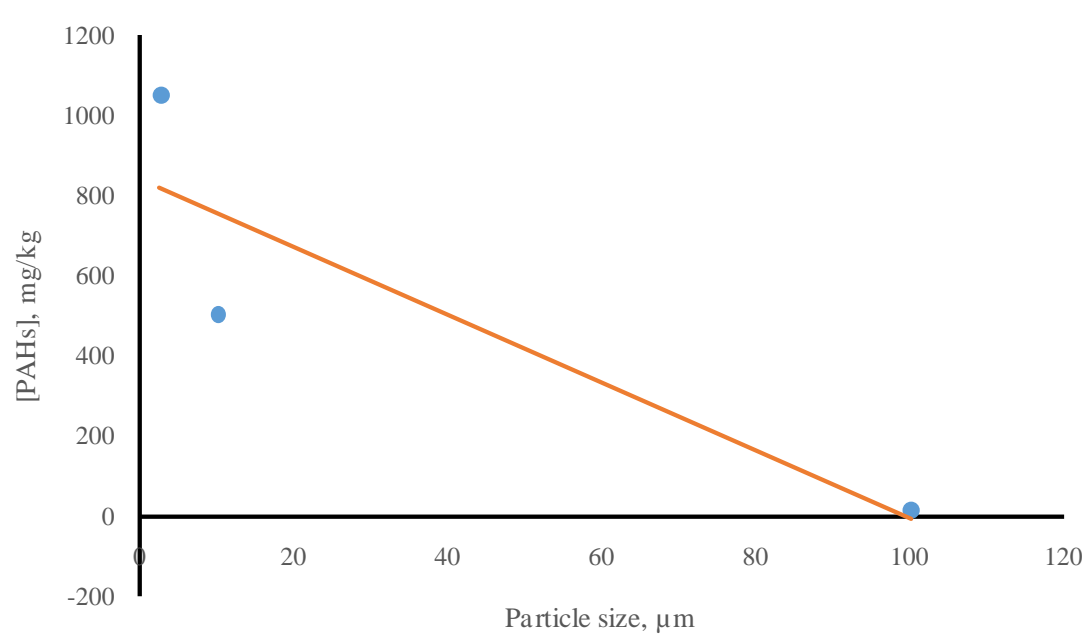

Figure 5. Correlation of PAHs content in the sample with particle size.

Table 3. Concentration of PAHs in environmental samples, $\mu \mathrm{g} / \mathrm{kg}$.

\begin{tabular}{ccccccccccccccc}
\hline S. No. & Phe & Ant & Fla & Pyr & Baa & Cry & Bbf & Bkf & Bap & Dba & Bgh & Ind & Cor \\
\hline RD1 & 3168 & 301 & 1921 & 2222 & 394 & 622 & 586 & 227 & 341 & 18 & 373 & 254 & 0 \\
RD2 & 2549 & 218 & 2669 & 2494 & 408 & 869 & 629 & 295 & 358 & 151 & 262 & 334 & 0 \\
RD3 & 3402 & 320 & 2874 & 2240 & 600 & 902 & 866 & 343 & 439 & 97 & 602 & 430 & 0 \\
RD4 & 3484 & 252 & 2208 & 2978 & 797 & 895 & 1078 & 442 & 710 & 28 & 582 & 632 & 0 \\
RD5 & 5022 & 763 & 4759 & 5258 & 1886 & 1595 & 1986 & 880 & 1636 & 103 & 1019 & 1124 & 0 \\
RD6 & 2636 & 178 & 3073 & 2254 & 781 & 1135 & 1358 & 480 & 732 & 200 & 670 & 677 & 0 \\
RD7 & 5688 & 797 & 4655 & 2928 & 414 & 490 & 468 & 175 & 275 & 496 & 156 & 194 & 0 \\
RD8 & 4622 & 732 & 3240 & 2974 & 713 & 826 & 931 & 398 & 720 & 226 & 521 & 550 & 0 \\
SL & 632 & 186 & 598 & 1056 & 439 & 365 & 990 & 318 & 637 & 132 & 1505 & 1122 & 0 \\
MW & 653 & 168 & 914 & 1598 & 642 & 658 & 1525 & 526 & 653 & 167 & 1564 & 601 & 0 \\
TPPW & 3240 & 120 & 1104 & 1056 & 154 & 708 & 168 & 145 & 204 & 84 & 204 & 1139 & 0 \\
AW & 1829 & 191 & 2149 & 2574 & 475 & 515 & 630 & 256 & 486 & 101 & 644 & 720 & 0 \\
(PM10)1* & 39.3 & 7.7 & 81.7 & 79.8 & 29.6 & 34.6 & 50.5 & 22.1 & 35.9 & 3.5 & 51.5 & 52.7 & 15.9 \\
(PM10)2* & 24.7 & 5.2 & 39.9 & 39.6 & 18.5 & 23.3 & 43.5 & 19.0 & 22.2 & 2.7 & 45.4 & 47.8 & 15.6 \\
(PM2.5)1* & 16.1 & 3.8 & 79.9 & 106.1 & 59.1 & 70.6 & 149.1 & 65.4 & 104.4 & 11.3 & 160.3 & 171.1 & 54.1 \\
(PM2.5)2* & 15.9 & 4.4 & 37.7 & 47.3 & 30.7 & 42.4 & 115.6 & 51.1 & 53.3 & 6.8 & 119.5 & 129.2 & 46.3 \\
\hline
\end{tabular}

$*=10^{3}$.

\subsection{Vertical Distribution of PAHs}

The vertical distribution of the PAHs from $0-30 \mathrm{~cm}$ in the sludge samples was studied, and presented in Figure 6. The $\sum$ PAHs content was strongly increased with increase of the sludge depth profile from $0-30 \mathrm{~cm}$, may be due to their poor adsorption with the geo-media. Among them, extremely high vertical distribution of compounds i.e. Fla, Pyr, Bbf and Bap was observed.

\subsection{Toxicities}

The toxicities of PAHs increases as the mass number increases, and seven PAHs (i.e. Pyr, Baa, Bbf, Bkf, Bap, Dba and Ind) are considered to be more toxic, may bedue to higher thermal stability and delocalization of 


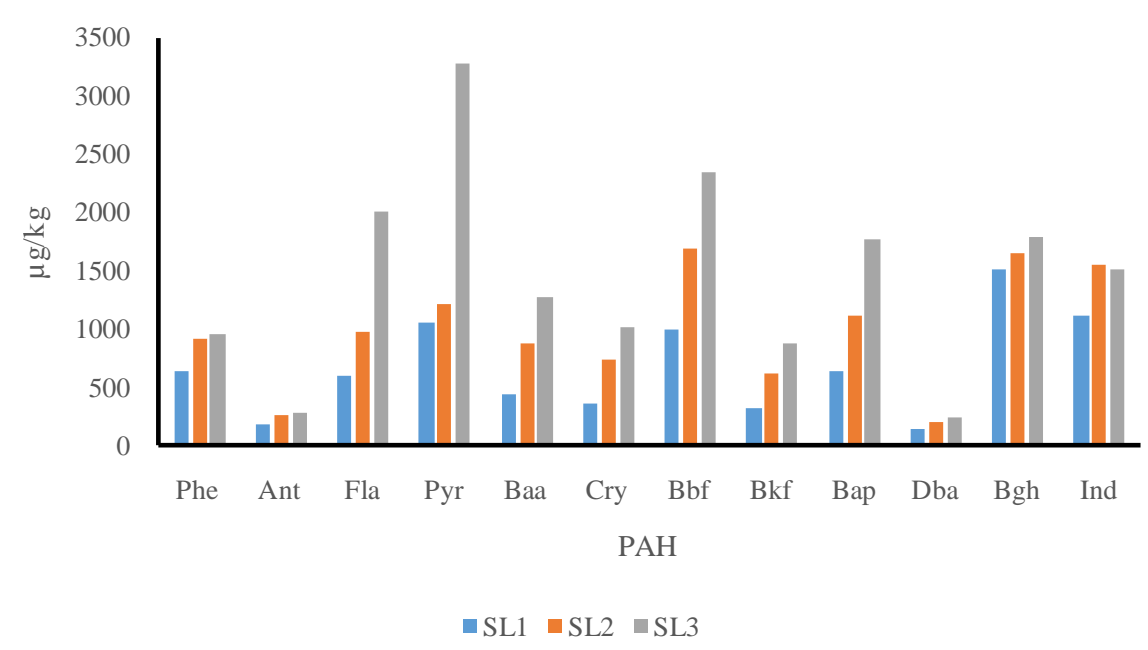

Figure 6. Vertical distribution of PAHs in the sludge, SL1 $=0-10 \mathrm{~cm}, \mathrm{SL} 2=10-20 \mathrm{~cm}$, $\mathrm{SL} 3=20-30 \mathrm{~cm}$.

$\pi$-electrons. The carcinogenic potentiality of Pyr, Baa, Bbf, Bkf, Bpa, Dba and Ind reported was 0.01, 0.1, 0.1, 0.1, 0.1, 1.0 and 0.1, respectively [28]. The benzo [a] pyrene equivalent (BapE) value was computed by using the following equation:

$$
\text { Total BapE }=\left[\sum_{i} C_{i}\right] \times\left[T E F_{i}\right]
$$

where, $C_{i}$ and $T E F_{i}$ are the concentration and the corresponding toxic equivalent factor (TEF) value of PAHs.

The BapE value for RD, SL, MW, AW, TPPW, $\mathrm{PM}_{10}$ and $\mathrm{PM}_{2.5}$ was found to be $1108,1135,1237,846,475$, 52,000 and 138,500 $\mu \mathrm{g} / \mathrm{kg}$ in the term of Bap. The carcinogenic fraction of PAHs in RD, SL, MW, AW, TPPW, $\mathrm{PM}_{10}$ and $\mathrm{PM}_{2.5}$ samples was ranged from 5.7\% - 15.7\% with significantly higher value for SL, MW and PM samples, Figure 7. The concentration of PAHs in the environmental samples was found to be several folds higher than recommended value of $1000 \mu \mathrm{g} / \mathrm{kg}$ [29].

\subsection{Correlation and Sources}

The correlation matrix of the carbons and PAHs are summarized in Table 4. The PAHs had fair correlation with the BC, OC and CC contents $(r=0.70-0.96)$, indicating their origin from the burning processes. The lower PAHs (i.e. Phe, Ant, Fla and Pyr) among themselves had fair correlation, may be due to existence of their larger fractions in the gaseous forms, Table 4. The higher PAHs (i.e. Baa, Cry, Bbf, Bkf, Bap, Bgh and Ind except Dba) among themselves had good correlation, indicating origin from the burning processes, Table 4.

The diagnosis ratios: Phe/Antand [Fla]/[Fla + Pyr] were used to find out the sources of PAHs in the studied samples [30] [31]. The Phe/Ant ratio for TPPW, RD, AW, SL, MW, $\mathrm{PM}_{10}$ and $\mathrm{PM}_{2.5}$ was found to be 27, 10.2, 9.6, 3.4, 3.9, 5.0 and 3.9, respectively, suggesting the domination of petrogenic PAHs in the TPPW, RD and AW samples, Figure 8. The [Fla]/[Fla + Pyr] ratio of $>0.5,0.5->0.4$ and $<0.4$ was used as signature for PAHs emission from combustion of grass, wood/ coal, petroleum and diesel, respectively [31]. The [Fla]/[Fla + Pyr] ratio was ranged from 0.36 - 0.52, indicating domination of biomass or coal origin PAHs in the RD, TPPW and $\mathrm{PM}_{10}$ samples, Figure 8.

\section{Conclusion}

The light PAHs (3 - 4 ring) was found to be dominated in the RD, TPPW, AW and PM10 samples unlikely to SL, MW and PM2.5 samples. Their origins were largely pyrogenic, emitted by combustion of biomass, coal and diesel. The higher PAHs (5 - 6 ring) was found to extremely enrich in the $\mathrm{PM}_{2.5}$ sample due to origin by the combustion processes. The PHAs concentration was remarkably increased vertically and might be due to poor adsorption by the geo-media. The PAHs content in the environmental samples of the studied area was found to be several folds higher than recommended value of $1000 \mu \mathrm{g} / \mathrm{kg}$. 


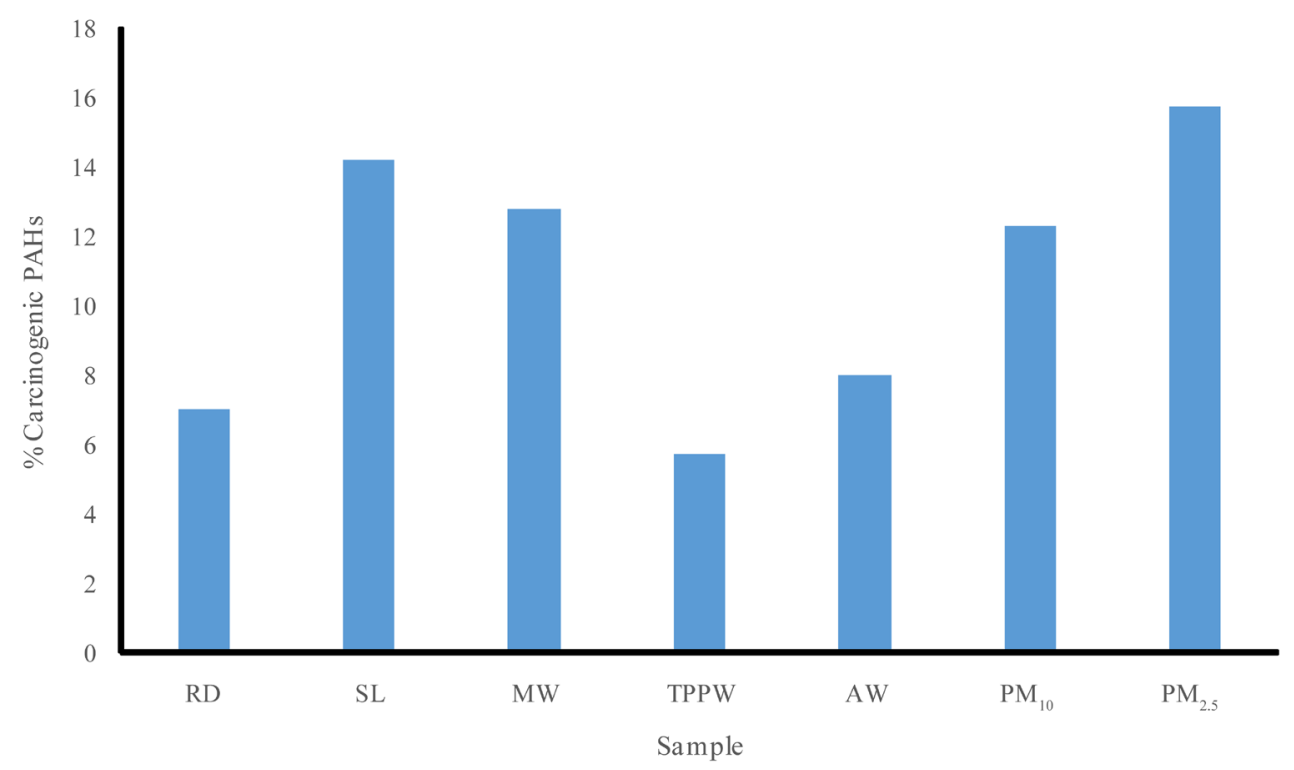

Figure 7. Percentage of carcinogenic PAHs in environmental samples.

(a)
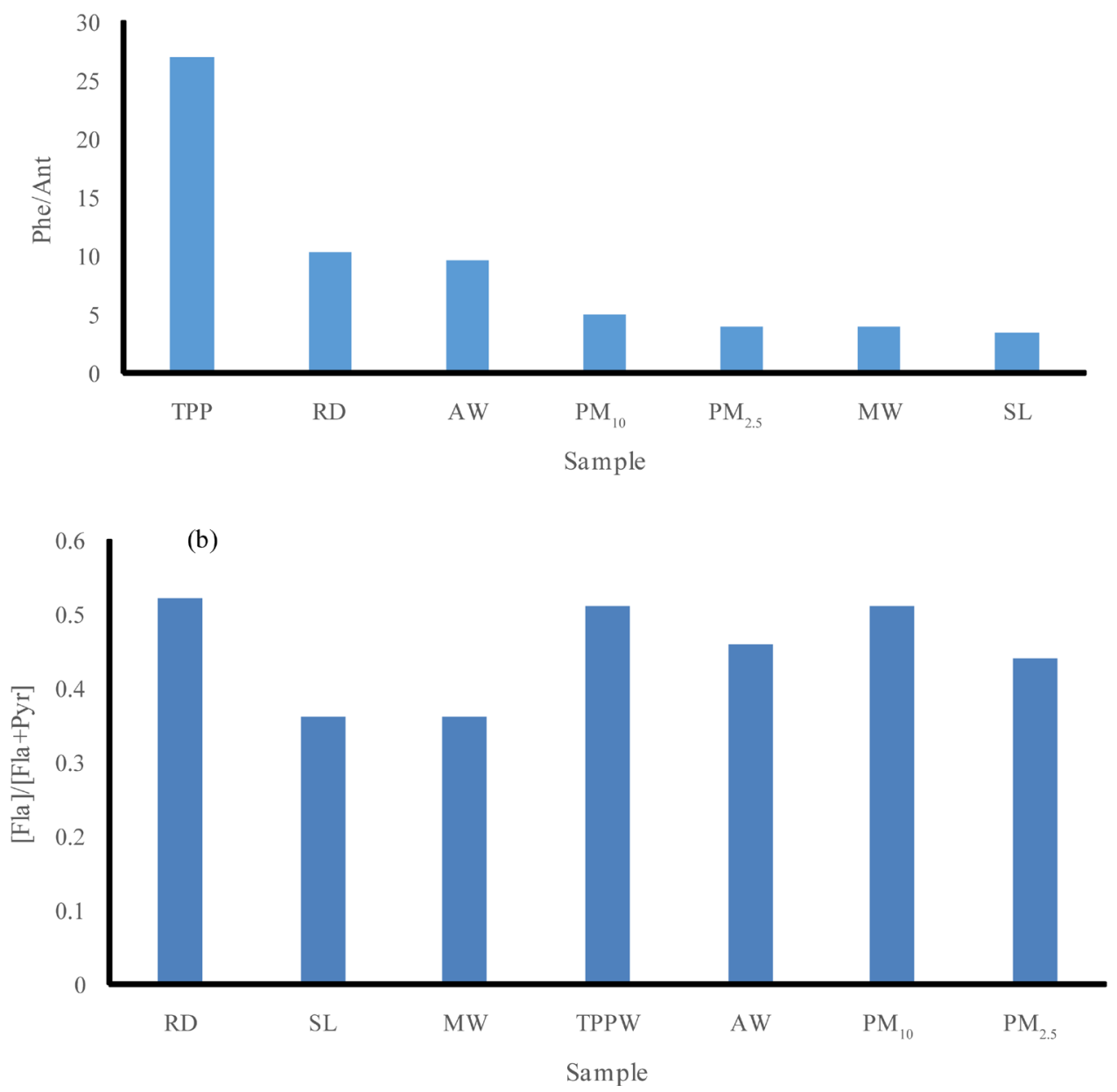

Figure 8. Diagnostic ratio for source determination of PAHs. 
Table 4. Correlation matrix of PAHs in the road dust.

\begin{tabular}{|c|c|c|c|c|c|c|c|c|c|c|c|c|}
\hline & Phe & Ant & Fla & Pyr & Baа & Cry & Bbf & Bkf & Bap & Dba & Bgh & Ind \\
\hline Phe & 1 & & & & & & & & & & & \\
\hline Ant & 0.96 & 1 & & & & & & & & & & \\
\hline Fla & 0.80 & 0.81 & 1 & & & & & & & & & \\
\hline Pyr & 0.61 & 0.64 & 0.69 & 1 & & & & & & & & \\
\hline Baa & 0.35 & 0.39 & 0.54 & 0.91 & 1 & & & & & & & \\
\hline Cry & -0.02 & 0.06 & 0.34 & 0.71 & 0.91 & 1 & & & & & & \\
\hline Bbf & 0.12 & 0.17 & 0.39 & 0.75 & 0.95 & 0.96 & 1 & & & & & \\
\hline Bkf & 0.18 & 0.24 & 0.42 & 0.83 & 0.98 & 0.97 & 0.98 & 1 & & & & \\
\hline Bap & 0.31 & 0.37 & 0.48 & 0.89 & 0.99 & 0.92 & 0.96 & 0.99 & 1 & & & \\
\hline Dba & 0.60 & 0.57 & 0.66 & -0.01 & -0.23 & -0.37 & -0.31 & -0.33 & -0.26 & 1 & & \\
\hline Bgh & 0.05 & 0.10 & 0.24 & 0.65 & 0.90 & 0.92 & 0.96 & 0.94 & 0.91 & -0.47 & 1 & \\
\hline Ind & 0.15 & 0.20 & 0.37 & 0.78 & 0.96 & 0.95 & 0.99 & 0.99 & 0.98 & -0.33 & 0.95 & 1 \\
\hline
\end{tabular}

\section{Acknowledgements}

We are thankful the CCOST, Raipur for granting research support for doing this work.

\section{References}

[1] Bjorseth, A. and Dennis, A. (1980) Proceedings of International Polynuclear Aromatic Hydrocarbon Symposia, PAHIV: Polynuclear Aromatic Hydrocarbons, Chemistry and Biological Effects. Battelle Press, Columbus, OH, 1125 p.

[2] Finlayson-Pitts, B.J. and Pitts, J.N. (2000) Chemistry of the Upper and Lower Atmosphere. Academic Press, San Diego.

[3] Pickering, R.W. (1999) A Toxicological Review of Polycyclic Aromatic Hydrocarbons. Journal of Toxicology—Cutaneous and Ocular Toxicology, 18, 101-135. http://dx.doi.org/10.3109/15569529909037562

[4] Baran, S. and Oleszczuk, P. (2003) The Concentration of Polycyclic Aromatic Hydrocarbons in Sewage Sludge in Relation to the Amount and Origin of Purified Sewage. Polish Journal of Environmental Studies, 12, 523-529.

[5] Pérez, S., Farré, M., Jesús Garcia, M. and Barceló, D. (2001) Occurrence of Polycyclic Aromatic Hydrocarbons in Sewage Sludge and their Contribution to its Toxicity in the ToxAlert ${ }^{\circledR} 100$ Bioassay. Chemosphere, 45, 705-712. http://dx.doi.org/10.1016/S0045-6535(01)00152-7

[6] Blanchard, M., Teil, M.J., Ollivon, D., Legenti, L. and Chevreuil, M. (2004) Polycyclic Aromatic Hydrocarbons and Polychlorobiphenyls in Wastewaters and Sewage Sludges from the Paris Area (France). Environmental Research, 95, 184-197. http://dx.doi.org/10.1016/j.envres.2003.07.003

[7] Harrison, E.Z., Oakes, S.R., Hysell, M. and Hay, A. (2006) Organic Chemicals in Sewage Sludge. Science of Total Environment, 367, 481-497. http://dx.doi.org/10.1016/j.scitotenv.2006.04.002

[8] Cai, Q.Y., Mo, C.H., Wu, Q.T., Zeng, Q.Y. and Katsoyiannis, A. (2007) Occurrence of Organic Contaminants in Sewage Sludges from Eleven Wastewater Treatment Plants, China. Chemosphere, 68, 1751-1762. http://dx.doi.org/10.1016/j.chemosphere.2007.03.041

[9] Lorenzi, D., Entwistle, J.A., Cave, M. and Dean, J.R. (2011) Determination of Polycyclic Aromatic Hydrocarbons in Urban Street Dust: Implications for Human Health. Chemosphere, 83, 970-977. http://dx.doi.org/10.1016/j.chemosphere.2011.02.020

[10] Tang, X., Shen, C., Cheema, S.A., Chen, L., Xiao, X., Zhang, C., Liu, W., Li, F. and Chen, Y. (2010) Levels and Distributions of Polycyclic Aromatic Hydrocarbons in Agricultural Soils in an Emerging e-waste Recycling town in Taizhou Area, China. Journal of Environmental Science and Health Part A, Toxic/Hazardous Substances and Environmental Engineering, 45, 1076-1084. http://dx.doi.org/10.1080/10934529.2010.486336

[11] Amuda, O.S. and Adelowo-Imeokparia, F.E. (2007) Polycyclic Aromatic Hydrocarbons in Municipal Waste Ashes from Three Waste Dumps in Lagos, Nigeria. Bulletin of the Chemical Society of Ethiopia, 21, 141-144.

http://dx.doi.org/10.4314/bcse.v21i1.61402 
[12] Pengchai, P., Nakajima, F. and Furumai, H. (2005) Estimation of Origins of Polycyclic Aromatic Hydrocarbons in Size-Fractionated Road Dust in Tokyo with Multivariate Analysis. Water Science and Technology, 51, 169-175.

[13] Boonyatumanond, R., Murakami, M., Wattayakorn, G., Togo, A. and Takada, H. (2007) Sources of Polycyclic Aromatic Hydrocarbons (PAHs) in Street Dust in a Tropical Asian Mega-City, Bangkok, Thailand. Science of the Total Environment, 384, 420-432. http://dx.doi.org/10.1016/j.scitotenv.2007.06.046

[14] Naspinski, C., Lingenfelter, R., Cizmas, L., Naufal, Z., He, L.Y., Islamzadeh, A., Li, Z.W., Li, Z., McDonald, T. and Donnelly, K.C. (2008) A Comparison of Concentrations of Polycyclic Aromatic Compounds Detected in Dust Samples from Various Regions of the World. Environment International, 34, 988-993. http://dx.doi.org/10.1016/j.envint.2008.03.008

[15] Hassanien, M.A. and Abdel-Latif, N.M. (2008) Polycyclic Aromatic Hydrocarbons in Road Dust over Greater Cairo, Egypt. Journal of Hazardous Materials, 151, 247-254. http://dx.doi.org/10.1016/j.jhazmat.2007.05.079

[16] Han, B., Bai, Z.P., Guo, G.H., Wang, F., Li, F., Liu, Q.X., Ji, Y.Q., Li, X. and Hu, Y.D. (2009) Characterization of $\mathrm{PM}_{10}$ Fraction of Road Dust for Polycyclic Aromatic Hydrocarbons (PAHs) from Anshan, China. Journal of Hazardous Materials, 170, 934-940. http://dx.doi.org/10.1016/j.jhazmat.2009.05.059

[17] Wang, W., Huang, M.J., Kang, Y., Wang, H.S., Leung, A.O., Cheung, K.C. and Wong, M.H. (2011) Polycyclic Aromatic Hydrocarbons (PAHs) in Urban Surface Dust of Guangzhou, China: Status, Sources and Human Health Risk Assessment. Science of the Total Environment, 409, 4519-4527. http://dx.doi.org/10.1016/j.scitotenv.2011.07.030

[18] Yu, B., Xie, X., Ma, L.Q., Kan, H. and Zhou, Q. (2013) Source, Distribution, and Health Risk Assessment of Polycyclic Aromatic Hydrocarbons in Urban Street Dust from Tianjin, China. Environmental Science and Pollution Research, 21, 2817-2825. http://dx.doi.org/10.1007/s11356-013-2190-z

[19] Mohd Radzi, N.A.S., Bakar, N.K.A., Emenike, C.U. and Abas, M.R. (2015) Polycyclic Aromatic Hydrocarbons (PAHs): Contamination Level and Risk Assessment in Urban Areas, Kuala Lumpur, Malaysia. Desalination and Water Treatment. http://dx.doi.org/10.1080/19443994.2015.1021103

[20] Martuzevicius, D., Kliucininkas, L., Prasauskas, T., Krugly, E., Kauneliene, V. and Strandberg, B. (2011) Resuspension of Particulate Matter and PAHs from Street Dust. Atmospheric Environment, 45, 310-317. http://dx.doi.org/10.1016/j.atmosenv.2010.10.026

[21] Sharma, H., Jain, V.K. and Khan, Z.H. (2007) Characterization and Source Identification of Polycyclic Aromatic Hydrocarbons (PAHs) in the Urban Environment of Delhi. Chemosphere, 66, 302-310. http://dx.doi.org/10.1016/j.chemosphere.2006.05.003

[22] Hassan, Y. and Sarma, H.P. (2013) Distribution of Polycyclic Aromatic Hydrocarbons (PAHS) in Roadside Soils from Industrial and High Traffic Area of Greater Guwahati City, Assam, India. Archives of Applied Science Research, 5, 85-93.

[23] Ray, S., Khillare, P.S., Kim, K.H. and Brown, R.J. (2012) Distribution, Sources, and Association of Polycyclic Aromatic Hydrocarbons, Black Carbon, and Total Organic Carbon in Size-Segregated Soil Samples Along a BackgroundUrban-Rural Transect. Environmental Engineering Science, 29, 1008-1019. http://dx.doi.org/10.1089/ees.2011.0323

[24] Cheng, H.R., Deng, Z.M., Chakraborty, P., Liu, D., Zhang, R.J., Xu, Y., Luo, C.L., Zhang, G. and Li, J. (2013) A Comparison Study of Atmospheric Polycyclic Aromatic Hydrocarbons in Three Indian Cities Using PUF Disk Passive Air Samplers. Atmospheric Environment, 73, 16-21. http://dx.doi.org/10.1016/j.atmosenv.2013.03.001

[25] Fu, F.F., Tian, B.Y., Lin, G.S., Chen, Y.Q. and Zhang, J.H. (2010) Chemical Characterization and Source Identification of Polycyclic Aromatic Hydrocarbons in Aerosols Originating from Different Sources. Journal of the Air and Waste Management Association, 60, 1309-1314. http://dx.doi.org/10.3155/1047-3289.60.11.1309

[26] Wingfors, H., Hägglund, L. and Magnusson, R. (2011) Characterization of the Size-Distribution of Aerosols and Particle-Bound Content of Oxygenated PAHs, PAHs, and n-Alkanes in Urban Environments in Afghanistan. Atmospheric Environment, 45, 4360-4369. http://dx.doi.org/10.1016/j.atmosenv.2011.05.049

[27] Lintelmann, J., Fischer, K., Karg, E. and Schroppel, A. (2005) Determination of Selected Polycyclic Aromatic Hydrocarbons and Oxygenated Polycyclic Aromatic Hydrocarbons in Aerosol Samples by High-Performance Liquid Chromatography and Liquid Chromatography-Tandem Mass Spectrometry. Analytical and Bioanalytical Chemistry, 381, 508-519. http://dx.doi.org/10.1007/s00216-004-2883-8

[28] EPA (2005) Air Toxics Hot Spots Program Risk Assessment Guidelines, Part II Technical Support Document for Describing Available Cancer Potency Factors. Office of Environmental Health Hazard Assessment, California Environmental Protection Agency, Sacramento.

[29] CCME (Canadian Council of Ministers of the Environment) (2008) Canadian Soil Quality Guidelines for Carcinogenic and Other Polycyclic Aromatic Hydrocarbons (PAHs). Environmental and Human Health Effects, Scientific Supporting Document, 218 p.

[30] Magi, E., Bianco, R., Ianni, C. and Carro, M.D. (2000) Distribution of Polycyclic Aromatic Hydrocarbons in the Sedi- 
ments of the Adriatic Sea. Environmental Pollution, 119, 91-98. http://dx.doi.org/10.1016/S0269-7491(01)00321-9

[31] Li, G.C., Xia, X.H., Yang, Z.F., Wang, R. and Voulvoulis, N. (2006) Distribution and Sources of Polycyclic Aromatic Hydrocarbons in the Middle and Lower Reaches of the Yellow River, China. Environmental Pollution, 144, 985-993. http://dx.doi.org/10.1016/j.envpol.2006.01.047 